\title{
Milk basic protein supplementation exerts an anti-inflammatory effect in a food-allergic enteropathy model mouse
}

\author{
Aiko Ono-Ohmachi, ${ }^{*} \dagger$ Haruyo Nakajima-Adachi, $\ddagger^{1}$ Yoshikazu Morita, ${ }^{*}$ Ken Kato, ${ }^{*}$ and Satoshi Hachimurał \\ *Milk Science Research Institute, Megmilk Snow Brand Co. Ltd., 1-1-2 Minamidai, Kawagoe, Saitama 350-1165, Japan \\ †Department of Production and Quality Assurance, Bean Stalk Snow Co. Ltd., 5-1, Yotsuyahonshio-cho, Shinjuku-ku, Tokyo 160-0003, Japan \\ $\ddagger$ Research Center for Food Safety, Graduate School of Agricultural and Life Sciences, University of Tokyo, 1-1-1 Yayoi, Bunkyo-ku, \\ Tokyo 113-8657, Japan
}

\section{ABSTRACT}

To examine novel functions of milk basic protein (MBP) in T-cell-related inflammatory diseases, such as autoimmune diseases and allergies, we evaluated the effects of MBP on the causative responses of ovalbumin (OVA)-specific $\mathrm{T}$ cells in a food-allergic enteropathy model, OVA23-3 mice, which express an OVA-specific T-cell receptor gene. The OVA-specific $\mathrm{CD}^{+} \mathrm{T}$ cells of the mesenteric lymph nodes (MLN) from OVA23-3 mice were cultured with $\mathrm{CD}_{11 \mathrm{c}^{+}}$dendritic cells of MLN from BALB/cA mice in the absence or presence of MBP following stimulation with OVA; then the levels of CD69 expression and the levels of cytokine production by $\mathrm{CD}^{+}{ }^{+} \mathrm{T}$ cells were measured to evaluate activation. The effects of MBP supplementation of OVA 23-3 mice were assessed by feeding a diet containing OVA (OVA diet) with or without MBP for $28 \mathrm{~d}$. Intestinal inflammation, together with activation and cytokine production of $\mathrm{CD} 4^{+} \mathrm{T}$ cells by MLN, as well as femoral bone mineral density, were measured. In in vitro culture, MBP inhibited excess activation and IL-4 production by $\mathrm{CD}^{+} \mathrm{T}$ cells. The supplementation of $\mathrm{MBP}$ to the OVA diet attenuated OVA-specific IgE production in OVA-diet-fed OVA23-3 mice and slightly resolved developing enteropathy caused by excess IL-4 production by $\mathrm{CD}^{+} \mathrm{T}$ cells. Feeding OVA diet to OVA23-3 mice exhibited bone loss accompanied with enteropathy, whereas MBP supplementation prevented bone loss and increased osteoprotegerin, an osteoclastogenesis inhibitory factor, in the mice. The inhibition of T-cell-activation in both MLN and bone marrow by MBP supplementation may help prevent increased $\operatorname{IgE}$ levels caused by excessive IL- 4 production and bone loss accompanied by enteropathy. Our findings show that MBP may help attenuate both T-cell-related inflammation and bone loss.

Received May 30, 2017.

Accepted October 27, 2017.

${ }^{1}$ Corresponding author: aryu@mail.ecc.u-tokyo.ac.jp
Key words: milk basic protein, food-allergic enteropathy, anti-inflammation, bone

\section{INTRODUCTION}

An increase in inflammatory diseases such as autoimmune diseases and allergies caused by T-cell activation (Lindelöf et al., 2009; Chen and Flies, 2013; Luo et al., 2015; Kuwabara et al., 2017) is becoming an important social problem. Inflammation is an essential reaction for host defense, but in food-allergic inflammation, excessive immune responses to food proteins cause severe symptoms in different tissues of the body, as well as in the intestinal tract. The prevalence of food allergies is apparently increasing (Simons et al., 2015; Grabenhenrich et al., 2016); thus, preventing food allergies is important. Food allergies are believed to be caused by abnormal Th2 immune responses to food allergens, and activated $\mathrm{CD} 4^{+} \mathrm{T}$ cells play a central role in several symptoms involving allergen-specific IgE production. Ovalbumin (OVA) is a leading egg allergen, and OVA-specific T-cell receptor transgenic mice (OVA23-3) show food allergic intestinal inflammation and weight loss when solely fed an OVA-based diet (Nakajima-Adachi et al., 2006). Severe intestinal inflammation in the OVA-fed mice was caused by the induction of excessive IL-4-producing $\mathrm{CD} 4^{+} \mathrm{T}$ cells in the mesenteric lymph nodes (MLN; Nakajima-Adachi et al., 2014). Recent clinical studies have shown that intestinal inflammation, such as inflammatory bowel disease and celiac disease caused by the ingestion of wheat gluten (Bernstein and Leslie, 2003; Bernstein, 2006; Alaedini and Greem, 2005; Gordon, 2006) is associated with an increased risk of osteoporosis. Receptor activator of NF- $\kappa$ B ligand (RANKL), a factor required for the differentiation, maturation, and activation of osteoclasts, and osteoprotegerin (OPG), a decoy receptor of RANKL, are known to be key factors in bone remodeling, and an imbalance in serum concentration of RANKL and OPG has been reported in inflammatory bowel disease and celiac patients (Silvennoinen et 
al., 1995; Franchimont et al., 2004; Taranta et al., 2004; Moschen et al., 2005; Fiore et al., 2006), suggesting a relationship between intestinal inflammation and bone loss. Given this potential relationship, it is important to determine whether bone loss occurs in OVA-fed OVA23-3 mice that develop enteropathy caused by excessive IL-4-producing $\mathrm{CD} 4^{+} \mathrm{T}$ cells.

Milk has long been accepted as a beneficial food because it contains various health nutrients essential for the human body. In addition, it has been found that milk contains immunomodulatory effective components such as lipids and proteins. Milk lipids such as polar lipids (phospholipids and sphingolipids), CLA, and n-3 long-chain PUFA are known to prevent diabetes and cardiovascular diseases to suppress chronic inflammation (Lordan and Zabetakis, 2017). Milk proteins, especially whey proteins, are also reported to suppress the inflammation, and prevent colitis and arthritis (Wong and Watson, 1995; Low et al., 2003). Milk whey proteins, particularly in those with basic properties, have been identified as anti-inflammatory bioactive compounds (Otani, 2006; Mohanty et al., 2016). Therefore, we have focused on proteins with alkaline isoelectric points, isolated the fraction containing them from defatted milk using a cation exchange chromatography, and named this protein fraction as milk basic protein (MBP). Milk basic protein is composed of some proteins; the principal protein components of MBP are lactoferrin ( $\mathbf{L F})$, lactoperoxidase (LPO), angiogenin (ANG), and cystatin $\mathrm{C}$ ( $\mathbf{C y s} \mathbf{C})$ as previously reported (Matsuoka et al., 2002; Aoe et al., 2005; Kruger et al., 2007; Morita et al., 2008, 2011, 2012; Ishida et al., 2017). In addition, other milk proteins such as high mobility group (HMG)-like protein and kininogen fragment $1 / 2$ are slightly included (Yamamura et al., 1999, 2000, 2006). It has also reported that the content of casein in MBP was only a trace amount [GRAS Notice 000196 (2006); Goodman et al., 2007]. In each protein component such as LF, LPO, ANG, and CysC purified from MBP, their own biological activities have not been fully examined. However, because no heat is added in the MBP preparation process, it is suggested that their conformation is preserved as it exists in fresh milk, that is, LF preparations from milk contained ANG (Tanigawa et al., 2001; Morita et al., 2012), and conversely, ANG preparation contained LF (Bharadwaj et al., 2009), suggesting that LF and ANG might form a complex structure. Therefore, it is possible that the components of MBP (at least LF and ANG) exert their functions as a complex when administrated.

Dietary supplementation with MBP prevented bone loss in ovariectomized animal models (Kato et al., 2000; Toba et al., 2000; Morita et al., 2012) and postmenopausal women (Aoe et al., 2001, 2005; Aoyagi et al.,
2010). In addition the previous studies imply that MBP improves bone remodeling by promoting osteoblastmediated bone formation and suppressing osteoclastmediated bone resorption (Yamamura et al., 1999, 2000; Matsuoka et al., 2002; Morita et al., 2008, 2011), although little is known about the immunomodulatory effects of MBP. We thought that it might be possible for MBP to function as a basic whey protein with antiinflammatory bioactive compounds as described above.

In this study, we examined the anti-inflammatory functions of MBP in T-cell-related inflammatory diseases by evaluating the suppressive effects of MBP on the causative responses of OVA-specific $\mathrm{CD} 4^{+} \mathrm{T}$ cells in OVA23-3 mice. The supplementation of MBP inhibited excessive IL- 4 production by $\mathrm{CD} 4^{+} \mathrm{T}$ cells, thereby possibility resolving the developing enteropathy, and also prevented bone loss in these mice. Therefore, MBP is a useful food for preventing both enteropathy and bone loss caused by T-cell-related inflammation.

\section{MATERIALS AND METHODS}

\section{Mice}

Six-week-old male BALB/cA mice were purchased from CLEA Japan Inc. (Tokyo, Japan), and OVA23-3 mice with a BALB/cA mouse genetic background were kindly provided by S. Habu (Tokai University School of Medicine). Mice were fed a commercial CE-2 diet (CLEA Japan Inc.) until they were used in the experiment. All mice were housed individually in stainlesssteel cages in a temperature- and humidity-controlled room $\left(23^{\circ} \mathrm{C}\right.$ and $40 \pm 5 \%$ relative humidity) with a $12 \mathrm{~h}$ light/dark cycle. The mice were treated in accordance with the animal experimentation regulations of the Milk Science Research Institute of Megmilk Snow Brand Co., Ltd., which are based on the guidelines proposed by the Science Council of Japan.

\section{Preparation of MBP}

The preparation of MBP from bovine milk was described by Toba et al. (2000). In brief, fresh bovine milk was defatted by centrifugation and loaded onto a column packed with a cation-exchange resin. Acidic milk protein including casein and lactose were removed in the flow through fractions, whereas the basic protein was bound to the cation-exchange resin. The column was thoroughly washed with deionized water, and then the adsorbed protein was eluted with $1 M$ sodium chloride. The eluted fraction was desalted using cellulose membrane (cutoff $14 \mathrm{kDa}$ ) and then lyophilized as MBP. The protein content of the MBP sample was determined to be $98 \%$ (wt/wt) by Kjeldahl method 
for nitrogen determination. The major components in MBP used in this experiment were quantified by ELISA (Matsuoka et al., 2002; Morita et al., 2011, 2012; Ishida et al., 2017); LF, LPO, ANG, and CysC were 53.6, $36.1,3.6$, and $0.05 \%$ (wt/wt), respectively.

\section{Diet and Feeding (MBP Supplementation)}

Diets containing OVA were generated by modifying the powdered AIN-76 diet (American Institute of Nutrition, 1977). Either 5\% (wt/wt) casein was replaced with OVA (Wako Pure Chemical Industry, Osaka, Japan) as a protein source (OVA diet), or 6\% (wt/ wt) casein was replaced with $5 \%$ (wt/wt) OVA and $1 \%$ (wt/wt) MBP (MBP/OVA diet). Seven- to nineweek-old male BALB/cA mice and OVA23-3 mice were separated into 3 groups: BALB/cA mice fed the OVA diet (OVA/BALB group), and OVA23-3 mice fed the OVA diet (OVA/OVA23-3 group) or the MBP/OVA diet (MBP/OVA/OVA23-3 group). The mice were housed individually and given free access to the diets throughout the experimental period. Body weights and food consumption were measured every 1 to $3 \mathrm{~d}$. Blood was taken from the ocular fundus at d 10 and 28 . At the end of the experimental period, the mice were killed by cervical dislocation and their lymphoid tissues $[\mathrm{MLN}$, spleen, and bone marrow $(\mathbf{B M})]$ and bones were removed for further analysis.

\section{Preparation of Single-Cell Suspensions and Purification of $C D 4^{+}$Cells and $C D 11 c^{+}$Cells}

Single-cell suspensions were prepared as follows; MLN, spleen, and BM were separately minced with a syringe plunger ( $5 \mathrm{~mL}$, Terumo, Tokyo, Japan) and then pressed through a $70-\mu \mathrm{m}$ cell strainer (BD Falcon, Bedford, MA). The cell suspensions were washed in complete RPMI 1640 medium (Thermo Fisher Scientific, Rockford, IL) supplemented with $10 \%$ fetal bovine serum (Thermo Fisher Scientific), $100 \mathrm{U} / \mathrm{mL}$ of penicillin/streptomycin (Thermo Fisher Scientific), 50 $\mu M$ 2-mercaptoethanol, and $10 \mathrm{~m} M$ HEPES (Thermo Fisher Scientific).

To analyze the effects of MBP on the inflammatory responses of $\mathrm{CD} 4^{+} \mathrm{T}$ cells in vitro and in vivo, $\mathrm{CD} 4^{+}$ cells of MLN from OVA23-3 mice and $\mathrm{CD}_{11 c^{+}}$cells of MLN from BALB/cA mice were isolated by magnetic-activated cell sorting (MACS; Miltenyi Biotec, Auburn, CA) according to the manufacturer's instructions. Briefly, single-cell suspensions were washed with MACS buffer [Ca- and $\mathrm{Mg}$-free PBS containing 0.1\% BSA and $2 \mathrm{~m} M$ EDTA]. Before labeling, nonspecific cell binding was blocked by incubating with $0.1 \mu \mathrm{g}$ of anti-Fc $\gamma$ R III/II (eBioscience, San Diego, CA) per $1 \times$
$10^{6}$ cells for $20 \mathrm{~min}$ at $4^{\circ} \mathrm{C}$. Cells were then labeled with anti-CD4 microbeads (Miltenyi Biotec) or anti-CD11 microbeads (Miltenyi Biotec) for 15 min at $4^{\circ} \mathrm{C}$ and washed twice with MACS buffer. Both $\mathrm{CD} 4^{+}$cells and $\mathrm{CD}_{11 \mathrm{c}^{+}}$cells were obtained by one passage over an LS Mini MACS column. The purities of the $\mathrm{CD}^{+}$cells and $\mathrm{CD}_{11 \mathrm{c}^{+}}$cells were $>90$ and $>80 \%$, respectively, as determined by flow cytometer.

\section{Flow Cytometry}

The following monoclonal antibodies (mAb) were used for the flow cytometry marker study. Fluorescein isothiocyanate (FITC)-anti-mouse CD69 mAb (clone H1.2F3) was obtained from Beckman Coulter Inc. (Brea, CA). Phycoerythrin and cyanine 5 (PE-Cy5)anti-mouse CD4 mAb (clone RM4-5) were obtained from eBioscience. FITC-anti-mouse CD11c mAb (clone HL3), FITC-rat IgG2a mAb (clone R35-95), and PECy5-rat IgG2a mAb (clone R35-95) were obtained from BD Pharmingen (San Diego, CA) as isotype-matched antibodies.

Single-cell suspensions of MLN, spleen, and BM were pre-incubated with $0.1 \mu \mathrm{g}$ of anti-Fc $\gamma \mathrm{R}$ III/II mAb per $1 \times 10^{6}$ cells for $20 \mathrm{~min}$ at $4^{\circ} \mathrm{C}$. The cells were then stained with $0.1 \mu \mathrm{g}$ of $\mathrm{mAb}$ per $1 \times 10^{6}$ cells for $30 \mathrm{~min}$ at $4^{\circ} \mathrm{C}$. After surface marker staining, the cells were resuspended in Dulbecco's PBS containing $1 \%$ BSA and $0.1 \%$ sodium azide, and then incubated at $4^{\circ} \mathrm{C}$ overnight. Dead cells were removed by staining with propidium iodide (BD Pharmingen) or 7-AAD Viability Dye (Beckman Coulter) according to the manufacturer's recommendations just before measurement. Isotype-matched antibodies of relevant specificity were used to determine the level of nonspecific staining. Target cells were measured on an EPICS-XL flow cytometer (Beckman Coulter) and then evaluated using CXP software (Beckman Coulter). Data were acquired for more than 100 cells of each target cell type.

\section{Effect of MBP on the Activation of $C D 4^{+} T$ Cells by Stimulation with OVA}

The $\mathrm{CD}^{+} \mathrm{T}$ cells and CD11c ${ }^{+}$dendritic cells (DC) were isolated from the MLN of 8-wk-old male OVA23-3 mice and 8-wk-old BALB/cA mice, respectively. The $\mathrm{CD} 4^{+} \mathrm{T}$ cells $\left(1 \times 10^{5}\right.$ cells/well $)$ and CD11c ${ }^{+}$DC $(1 \times$ $10^{4}$ cells/well) were cultured in a 96-well plate (Iwaki, Tokyo, Japan) in the presence of $0,0.1$, and $1 \mathrm{mg} /$ $\mathrm{mL}$ of OVA (Seikagaku-Kogyo, Tokyo, Japan) and 0, 0.01 , and $0.1 \mathrm{mg} / \mathrm{mL}$ of $\mathrm{MBP}$ or protease-free BSA (Millipore, Bedford, MA) at $37^{\circ} \mathrm{C}$ in $5 \% \mathrm{CO}_{2}$ for $72 \mathrm{~h}$. Because OVA, MBP, and BSA were soluble in PBS, we used PBS-dissolved-OVA, MBP, and BSA for the cul- 
ture. All solutions were sterilized by filtering through a $0.22-\mu \mathrm{m}$ membrane (Millipore) before use. The concentration of MBP was determined to be appropriate for T-cell analysis in accordance with previous studies evaluating the effect of LF or LPO on T-cell-activation (Wong et al., 1997). The cells were collected, and the frequency of CD69 molecules expressed on the CD4 ${ }^{+} \mathrm{T}$ cells was measured by flow cytometer.

\section{Serum Biomarkers}

Serum was obtained by centrifuging blood samples at $3,000 \times g$ at $4^{\circ} \mathrm{C}$ for $30 \mathrm{~min}$, and the serum samples were stored at $-80^{\circ} \mathrm{C}$ until analysis. The serum concentrations of calcium, inorganic phosphorus, albumin, and protein were measured by using a clinical chemistry system (Fuji Dri-Chem, Fujifilm, Tokyo, Japan), and the serum concentration of cytokines (RANKL and OPG) was measured by ELISA.

\section{Cytokine Measurement by ELISA}

The concentrations of IL-2, IL-4, IFN- $\gamma$, RANKL, and OPG in the cell culture supernatant or serum were determined by using a commercial ELISA kit (R\&D Systems, Minneapolis, MN) according to the manufacturer's instructions. Briefly, a coating antibody was diluted 100-fold with $0.05 \mathrm{M} \mathrm{NaHCO}_{3}(\mathrm{pH} 9.6)$, added to a 96-well plate (NUNC, Roskilde, Denmark), and incubated overnight at $4^{\circ} \mathrm{C}$. The plate was blocked with Dulbecco's PBS containing protease-free BSA for $1 \mathrm{~h}$ at room temperature. Samples and standards were added and reacted with the coating antibody for $1 \mathrm{~h}$. The samples and standards were reacted with biotinylated antibodies for $1 \mathrm{~h}$, and then avidin-horseradish peroxidase (BD Biosciences, San Jose, CA) was added and the plate was incubated for $1 \mathrm{~h}$. After washing, a fluorogenic substrate (Quanta Blu, Pierce, Rockford, IL) was added and reacted for $1 \mathrm{~h}$, then stop solution $(100 \mu \mathrm{L}$ per well) was added and the fluorescence was measured with a multi-well plate reader (CytoFluor Series 4000, PerSeptive Biosystems Inc., Framingham, MA).

\section{Histological Analysis}

Histological analysis was performed as described by a previous report (Nakajima-Adachi et al., 2006). After the 28-d experimental periods, longitudinal sections of intestinal tissue $(3 \mathrm{~cm})$ were taken from lower small intestine (the superior part of the cecum). Tissues were fixed in $10 \%$ formalin for $24 \mathrm{~h}$ and embedded in paraffin. Sections, $3 \mu \mathrm{m}$ thick, were prepared and stained with hematoxylin and eosin solution.

\section{Serum OVA-Specific IgE Level}

The 96-well microplates (NUNC) were coated with 100-fold diluted goat anti-mouse IgE antibody (Bethyl Laboratories, Montgomery, TX) in $0.05 \mathrm{M} \mathrm{NaHCO}_{3}$ (pH 9.6) and incubated overnight at $4^{\circ} \mathrm{C}$. After blocking, serum samples were added and incubated for 1 $\mathrm{h}$, the wells were washed, biotin-conjugated OVA was added, the samples were incubated for $1 \mathrm{~h}$, then the plates were treated with streptavidin-alkaline phosphatase. After washing, peroxidase substrate (Quanta Blu) was added and reacted for $1 \mathrm{~h}$, then the absorbance was measured at $405 \mathrm{~nm}$ with a multi-well plate reader (CytoFluor Series 4000).

\section{Dual-Energy X-Ray Absorptiometry Analysis of Bone}

Femur bone mineral density (BMD) was measured at $\mathrm{d} 10$ and 28 during the experiment by dual-energy x-ray absorptiometry using a bone densitometer (Dichroma Scan DCS-600A, Aloka, Tokyo, Japan) with a beam energy of $22 \mathrm{keV}$ adapted for measuring small animals under pentobarbital-induced anesthesia (Somnopentyl, Kyoritsu Seiyaku, Tokyo, Japan). The scanning speed was $10 \mathrm{~mm} / \mathrm{s}$, and each scanning step was $1 \mathrm{~mm}$. The BMD of each segment was calculated by dividing the whole femur into 3 parts of equal length to assess differences in the various regions of the bone.

\section{Statistical Analysis}

All data are expressed as mean \pm SD. For parametric data, a one-way ANOVA was performed, and significant differences between groups were determined by the Tukey-Kramer post hoc test. All statistical calculations were done using StatView version 5 (SAS Institute Inc., Cary, NC). Differences were considered statistically significant at $P<0.05$.

\section{RESULTS}

\section{Treatment of MBP Suppresses OVA-Induced Cytokine Production by Inhibiting the Activation of T Cells In Vitro}

To evaluate the effect of MBP on T-cell-activation, the expression of CD69, a T-cell-activation marker, and cytokine production by $\mathrm{CD} 4^{+} \mathrm{T}$ cells were assayed in an in vitro culture of $\mathrm{CD}^{+} \mathrm{T}$ cells and $\mathrm{CD} 11 \mathrm{c}^{+}$ DC following stimulation with OVA. The percentage of $\mathrm{CD} 69^{+} \mathrm{CD} 4^{+} \mathrm{T}$ cells in $\mathrm{CD} 4^{+} \mathrm{T}$ cells increased in a dose-dependent manner upon stimulation with OVA. When MBP was added to the culture, OVA-induced CD69 expression on $\mathrm{CD}^{+} \mathrm{T}$ cells was significantly 
suppressed in a MBP dose-dependent manner $(P<$ 0.05), compared with cells stimulated with OVA alone (Figure 1A). The production of IL-2, IL-4, and INF- $\gamma$ by $\mathrm{CD} 4^{+} \mathrm{T}$ cells increased dose dependently following stimulation with OVA, whereas those productions by $\mathrm{CD}^{+} \mathrm{T}$ cells stimulated with OVA were inhibited in a dose-dependent manner by co-incubation with MBP (Figure 1B, 1C, and 1D). In contrast, neither CD69 expression nor cytokine production was affected by BSA. These results indicate that MBP can suppress the activation of OVA-specific activation of $\mathrm{CD} 4^{+} \mathrm{T}$ cells in response to OVA, thereby reducing their IL-2, IL- 4 , and IFN- $\gamma$ production.

\section{Supplementation of MBP Suppresses the Level of Serum OVA-Specific IgE in Food-Allergic Enteropathy Model Mice}

A previous study reported that OVA-specific $\mathrm{CD} 4^{+} \mathrm{T}$ cells produce IL-4 excessively in MLN, thereby inducing severe intestinal inflammation after oral administration of OVA to OVA23-3 mice (Nakajima-Adachi et al., 2014). Our present results using in vitro culture indicated that MBP inhibits the activation of $\mathrm{T}$ cells and IL- 4 production by $\mathrm{CD} 4^{+} \mathrm{T}$ cells, suggesting that MBP may prevent intestinal inflammation. Therefore, we used MBP as a dietary supplement for OVA-fed OVA23-3 mice and evaluated the effects of MBP on the development of intestinal inflammation, weight loss, activation of $\mathrm{T}$ cells, and cytokine production. During a 28-d-experimental OVA-feeding period, the BW of both the OVA/OVA23-3 and the MBP/OVA/ OVA23-3 groups decreased until $d 6$, then recovered but remained lower than that of the OVA/BALB group (Figure 2). The loss of BW by the MBP/OVA/ OVA23-3 group tended to decrease compared with that of the OVA/OVA23-3 group. In contrast, the BW of the OVA/BALB group increased throughout the experimental period. The amount of food intake throughout the experimental period and serum parameters (calcium, phosphorus, albumin, and total protein) at d 10 and 28 during the experimental period were within the normal range for all groups (the OVA/BALB, the OVA/OVA23-3, and the MBP/OVA/OVA23-3 groups) of mice, and the values were not significantly different among the 3 groups (Tables 1 and 2). These findings indicate that severe malnutrition did not occur in the OVA/OVA23-3 and MBP/OVA/OVA23-3 groups, although they exhibited BW loss by OVA feeding. In histological analysis, inflammatory changes, such as induction of goblet cells in villi and crypt elongation, were observed in the OVA/OVA23-3 group, but these changes were not so severe as to cause morphological changes in the villi. However, the inflammatory changes were less pronounced in the MBP/OVA/OVA23-3 group (Figure 3A). These results did not clearly show attenuation of intestinal inflammation in OVA/OVA23-3 mice by MBP supplementation. The increase in serum OVA-specific IgE production correlates with the severity of enteropathy (Nakajima-Adachi et al., 2006), and thus we also measured the production of OVA-specific $\operatorname{IgE}$ in sera from each group and compared the values among the 3 groups. The serum OVA-specific IgE level at d 10 in the OVA/OVA23-3 group was 2.5 times higher than that of the OVA/BALB group, whereas the level in the MBP/OVA/OVA23-3 group was one-half of that of the OVA/OVA23-3 group (Figure 3B). At d 28, no differences in the levels of serum OVA-specific IgE were observed among the 3 groups, showing that the level of serum OVA-specific IgE at d 28 decreased compared with those at d 10 in the OVA/OVA 23-3 group. Nakajima-Adachi et al. (2017) revealed that in this model, pathogenetic T-cell-related inflammation was induced and enteropathy was developed; however, regulatory $\mathrm{T}$ cells (Tregs) were simultaneously induced by long-term administration of OVA diet until d 28 of this experiment. By the regulatory activities, inflammatory activation of $\mathrm{T}$ cells was inhibited at $\mathrm{d}$ 28 , thereby leading to suppression of the production of IgE antibody by B cells in the OVA/OVA23- 3 group. As a result, no difference in the levels of serum OVAspecific IgE between OVA/OVA23-3 and MBP/OVA/ OVA23-3 groups was observed.

The IL-4-producing CD4 ${ }^{+} \mathrm{T}$ cells in MLN are thought to play an essential role in the onset of enteropathy in OVA-fed OVA23-3 mice (Nakajima-Adachi, et al., 2014), and thus we examined whether or not the properties of $\mathrm{CD}^{+} \mathrm{T}$ cells changed following MBP supplementation. The percentage of $\mathrm{CD} 69^{+} \mathrm{CD} 4^{+} \mathrm{T}$ cells in the total $\mathrm{CD} 4^{+} \mathrm{T}$ cells increased significantly in the MLN, spleen, and BM at d 28 in the OVA/OVA23-3 group compared with those of the OVA/BALB group (4.6, 5.1, and 2.0 times increase, respectively). The level of the $\mathrm{CD}^{+} \mathrm{T}$ cells in all lymphoid tissues in the MBP/OVA/OVA23-3 group was two-thirds of that of the OVA/OVA23-3 group (Figure 4A). The levels of $\mathrm{CD} 69^{+} \mathrm{CD} 4^{+} \mathrm{T}$ cells in both MLN and spleens in the MBP/OVA/OVA23-3 group 3.3 times increased compared with that of the OVA/BALB group, but their levels in the BM were similar. The production of IL-4 and IFN- $\gamma$ by $\mathrm{CD}^{+} \mathrm{T}$ cells in the MLN at $\mathrm{d} 28$ was significantly increased in the OVA/OVA23-3 group compared with those of the OVA/BALB group (4.1 and 6.5 times increase, respectively). However, their levels in the MBP/OVA/OVA23-3 group were one-quarter in IL-4 and two-fifths in IFN- $\gamma$ of those of the OVA/ OVA23-3 group (Figure 4B, 4C). These results show that MBP supplementation suppressed the production 
A

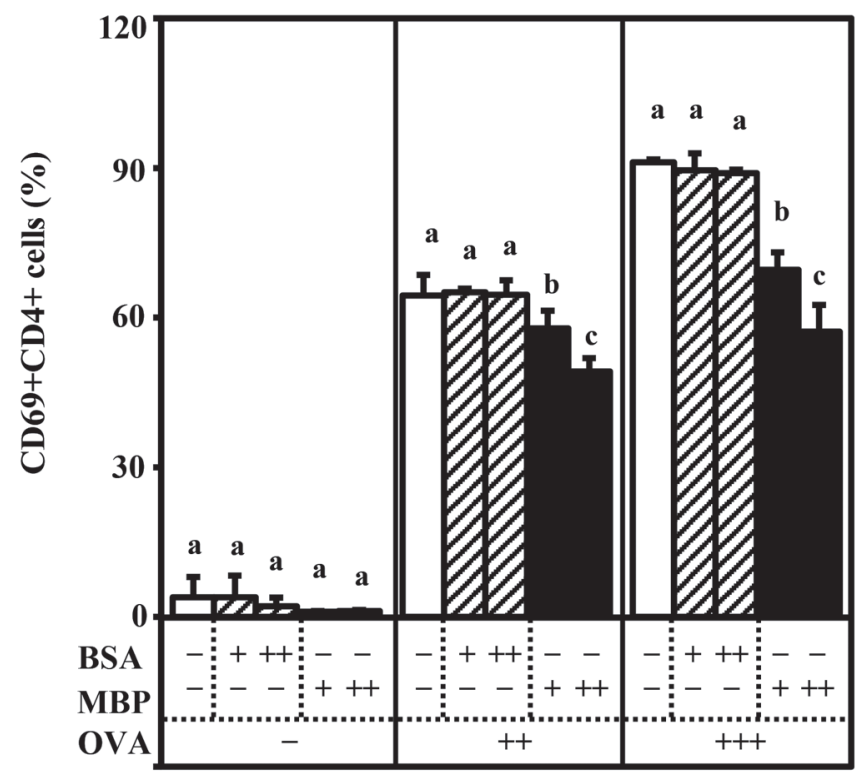

C

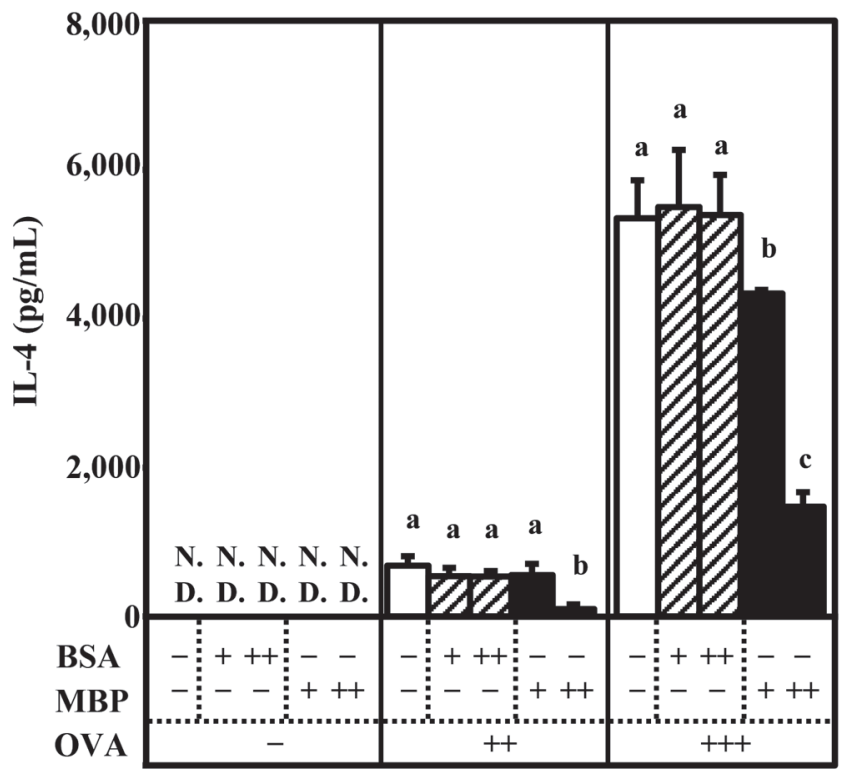

B

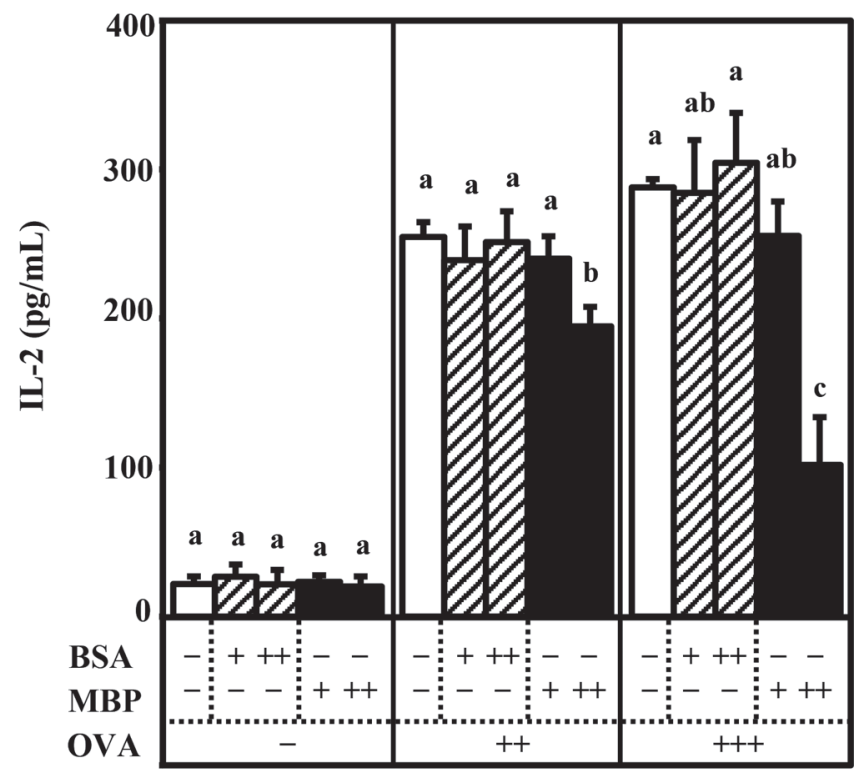

D

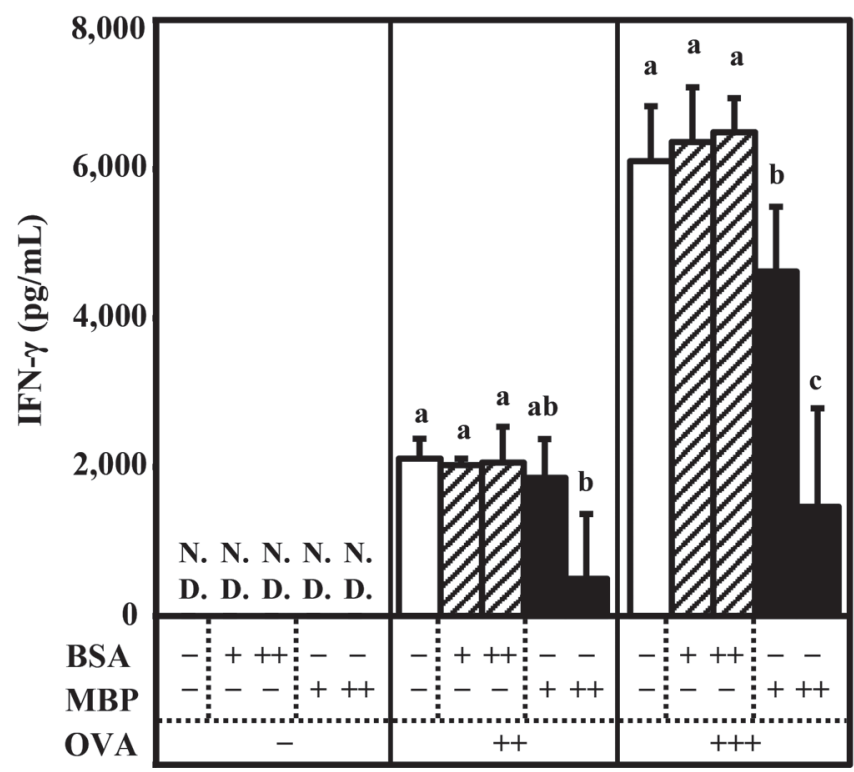

Figure 1. Effect of milk basic protein (MBP) on cytokine production in vitro. The co-culture of mesenteric lymph node (MLN)-CD4 ${ }^{+} \mathrm{T}$ cells derived from OVA23-3 mice and MLN-CD11 ${ }^{+}$dendritic cells derived from BALB/cA mice were activated with ovalbumin $(\mathrm{OVA})$ in the presence of BSA (diagonal striped bar), MBP (black bars) or PBS (white bar). Concentrations of 0, 0.01, 0.1, and 1.0 mg/mL (OVA, BSA, and MBP) are indicated as,,-+++ , and +++ , respectively. (A) The frequency of CD $69^{+} \mathrm{CD} 4^{+} \mathrm{T}$ cells in the total CD $4^{+} \mathrm{T}$ cell population, and the concentrations of IL-2 (B), IL-4 (C), and IFN- $\gamma$ (D) were analyzed. Each value is given as mean \pm SD, $\mathrm{n}=3$ for each group. Different letters represent significant differences, $P<0.05$, as determined by a post hoc Tukey-Kramer test. N.D. $=$ not determined.

of IL- 4 and IFN- $\gamma$ by inhibiting the activation of CD4 $4^{+}$ $\mathrm{T}$ cells in the MLN, thereby preventing the progression of T-cell-dependent food-allergic enteropathy. In addition, feeding the OVA diet to OVA23-3 mice increased the activation of $\mathrm{T}$ cells not only in the MLN, but also in the spleen and BM, whereas MBP supplementation decreased their activation, suggesting that MBP may suppress systemic inflammation. 
Table 1. Effect of milk basic protein $(\mathrm{MBP})$ on food intake in food-allergy model mice (mean $\pm \mathrm{SD}, \mathrm{n}=6$ for each group) ${ }^{1}$

\begin{tabular}{lccc}
\hline Item & OVA/BALB & OVA/OVA23-3 & MBP/OVA/OVA23-3 \\
\hline Food intake $(\mathrm{g})$ & $108.40 \pm 1.47$ & $108.68 \pm 2.42$ & $110.55 \pm 1.37$
\end{tabular}

${ }^{1}$ OVA $=$ ovalbumin; OVA/BALB group $=$ BALB $/$ cA mice were fed the OVA diet; OVA $/$ OVA23-3 group = OVA23-3 mice were fed the OVA diet; MBP/OVA/OVA23-3 group = OVA23-3 mice were fed the MBP/OVA diet.

Table 2. Serum biomarkers and cytokines (mean $\pm \mathrm{SD}, \mathrm{n}=6$ for each group $)^{1}$

\begin{tabular}{lccc}
\hline Item & OVA/BALB & OVA/OVA23-3 & MBP/OVA/OVA23-3 \\
\hline Calcium (mg/dL) & $9.27 \pm 0.47$ & $9.65 \pm 0.44$ & \\
d 10 & $9.48 \pm 0.62$ & $9.35 \pm 0.27$ & $9.82 \pm 0.72$ \\
d 28 & & & \\
Phosphorus (mg/dL) & $4.13 \pm 1.32$ & $4.97 \pm 1.60$ & $3.97 \pm 1.56$ \\
d 10 & $6.03 \pm 1.15$ & $4.50 \pm 1.95$ & $4.70 \pm 1.42$ \\
d 28 & $2.78 \pm 0.06$ & $2.70 \pm 0.09$ & $2.76 \pm 0.09$ \\
Albumin (g/dL) & $2.92 \pm 0.16$ & $2.87 \pm 0.02$ & $2.97 \pm 0.08$ \\
d 10 & & & \\
d 28 & $6.80 \pm 0.15$ & $6.13 \pm 0.16$ & $6.03 \pm 0.14$ \\
Total protein (g/dL) & $6.55 \pm 0.22$ & $6.16 \pm 0.07$ & \\
d 10 & & & \\
d 28 & $1,509.78 \pm 160.76$ & $1,601.59 \pm 161.76$ & $1,679.64 \pm 168.20$ \\
OPG (pg/mL) & $1,516.72 \pm 196.52^{\mathrm{a}}$ & $1,811.76 \pm 209.39^{\mathrm{b}}$ & $2,091.92 \pm 162.97^{\mathrm{c}}$ \\
d 10 & & & \\
d 28 & & & \\
\hline
\end{tabular}

${ }^{\mathrm{a}-\mathrm{c}}$ Different superscripts indicate significant differences, $P<0.05$, as determined by a post hoc Tukey-Kramer test.

${ }^{1} \mathrm{MBP}=$ milk basic protein OVA $=$ ovalbumin; $\mathrm{OPG}=$ osteoprotegerin; OVA $/$ BALB group $=\mathrm{BALB} / \mathrm{cA}$ mice were fed the OVA diet; OVA/OVA23-3 group = OVA23-3 mice were fed the OVA diet; MBP/OVA/OVA23-3 group $=$ OVA23-3 mice were fed the MBP/OVA diet.

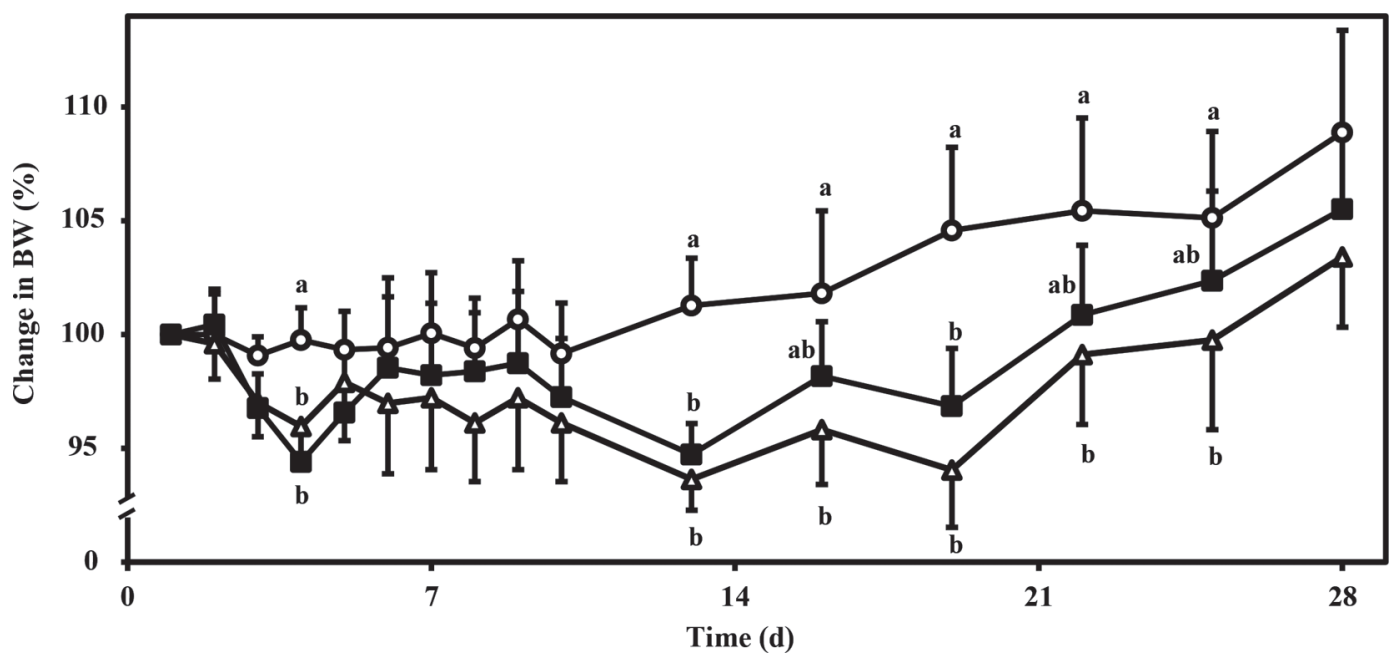

Figure 2. Effect of milk basic protein (MBP) on the weight change of food-allergic enteropathy model mice. The changes of BW in each experimental group were indicated; BALB/cA mice fed the ovalbumin (OVA) diet (OVA/BALB group, O), and OVA23-3 mice fed the OVA diet (OVA/OVA23-3 group, $\Delta$ ) or the MBP/OVA diet (MBP/OVA/OVA23-3 group, $\mathbf{0}$ ). Each value is mean $\pm \mathrm{SD}, \mathrm{n}=6$ for each group. Different letters represent significant differences, $P<0.05$, as determined by a post hoc Tukey-Kramer test. 
A
A OVA/BALB

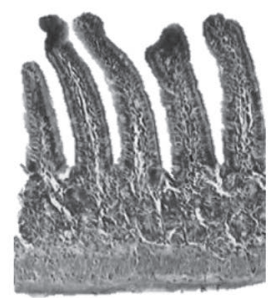

OVA/OVA23-3

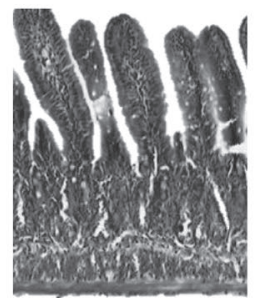

MBP/ OVA/OVA23-3

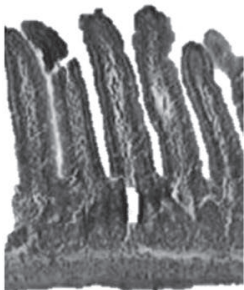

B

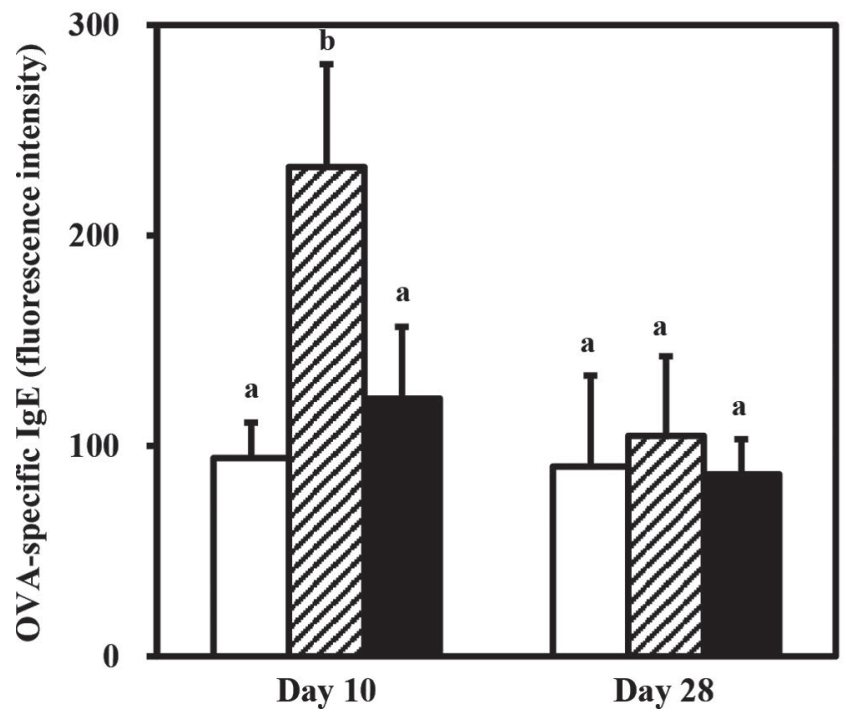

Figure 3. Effect of milk basic protein (MBP) on intestinal inflammation in food-allergic enteropathy model mice. (A) Histology of small intestine of ovalbumin (OVA)-diet-fed or MBP/OVA-diet-fed groups at d 28 of experimental diet feeding, and (B) the levels of serum IgE at $\mathrm{d} 10$ and 28 in BALB/cA mice fed the OVA diet (OVA/BALB group, white bar), and OVA23-3 mice fed the OVA diet (OVA/OVA233 group, diagonal striped bar) or the MBP/OVA diet (MBP/OVA/ OVA23-3 group, black bar). Each value is mean $\pm \mathrm{SD}, \mathrm{n}=6$ for each group. Different letters indicate significant differences, $P<0.05$, as determined by a post hoc Tukey-Kramer test.

\section{Supplementation of MBP Alleviates Bone Loss Accompanying Food-Allergic Enteropathy}

Intestinal inflammation due to autoimmune diseases has been reported to be accompanied by bone loss as described above. We noticed that enteropathy occurred in OVA-fed OVA23-3 mice in a T-cell-dependent manner, and thus we examined whether or not the mice exhibit bone loss. The BMD in the diaphyseal region of the femurs of the OVA/OVA23-3 group decreased by $3.4 \%$ compared with that of the OVA/BALB group at $\mathrm{d} 28$, whereas the BMD in the diaphyseal region in the MBP/OVA/OVA23-3 group increased by $3.3 \%$ compared with that of the OVA/OVA23-3 group (Table 3 ). In addition, the serum OPG level at d 28 in the OVA/
OVA23-3 group was $19.5 \%$ higher than that of the OVA/BALB group, but in the MBP/OVA/OVA23-3 group the serum OPG level was $37.9 \%$ higher than that of the OVA/BALB group and $15.5 \%$ higher than that of the OVA/OVA23-3 group (Table 2). The serum RANKL level was below the detection limit for all samples. Therefore, feeding the OVA diet to OVA23-3 mice leads to bone loss, whereas MBP supplementation prevents both bone loss with developing enteropathy, suggesting that MBP systemically functions to suppress inflammation induced by OVA-feeding.

\section{DISCUSSION}

The current study demonstrated a novel MBP function by showing that MBP exhibits an anti-allergic inflammatory effect, inhibiting the antigen-specific activation of $\mathrm{T}$ cells. Co-culture of MBP with OVA suppressed the antigen-specific activation and production of Th2 and Th1 cytokines by OVA-specific CD4 ${ }^{+}$ $\mathrm{T}$ cells purified from food-allergic enteropathy model mice. Remarkably, we found that MBP plays a role in inhibiting IL-4 production by OVA-specific $\mathrm{CD} 4^{+} \mathrm{T}$ cells. This inhibitory effect has not been reported for LF, a major component protein of MBP. Based on this finding, we further showed that MBP supplementation to OVA-fed OVA23-3 mice (food-allergic enteropathy model mice) suppressed food-allergic inflammatory responses [i.e., suppression of the level of $\mathrm{CD} 69^{+} \mathrm{CD} 4^{+}$ $\mathrm{T}$ cells (activated $\mathrm{CD} 4^{+} \mathrm{T}$ cells), production of excess IL- 4 by $\mathrm{CD}^{+} \mathrm{T}$ cells in MLN, and an increase in serum OVA-specific IgE levels].

It have been reported that LF and LPO show suppressive effects on cell proliferation and IL-2 production in T cells (Fischer et al., 2006; Legrand, 2012, 2016), consistent with our present results. Notably, our results indicate that MBP, which contains LF, inhibits IL-4 production, even though LF was reported to promote IL-4 production in an animal study (Togawa et al., 2002) and to not inhibit IL-4 production in an in vitro study (Zimecki et al., 1996). The MBP was known to include several components such as LF, LPO, ANG, CysC, HMG-like protein, and kininogen fragment $1 / 2$ as described above. From our current study, other components of MBP that constitute approximately half of the weight of MBP as described in Materials and Methods, rather than LF, are thought to show an inhibitory effect on IL-4 production by $\mathrm{CD}^{+}{ }^{\mathrm{T}}$ cells. In addition, LF function that promotes IL-4 production might be attenuated by the interaction of the other components (such as ANG) in MBP. Therefore, it should be examined to clear that in the future. A recent study focusing on regulatory responses (tolerance) in food-allergic enteropathy mice revealed 
A

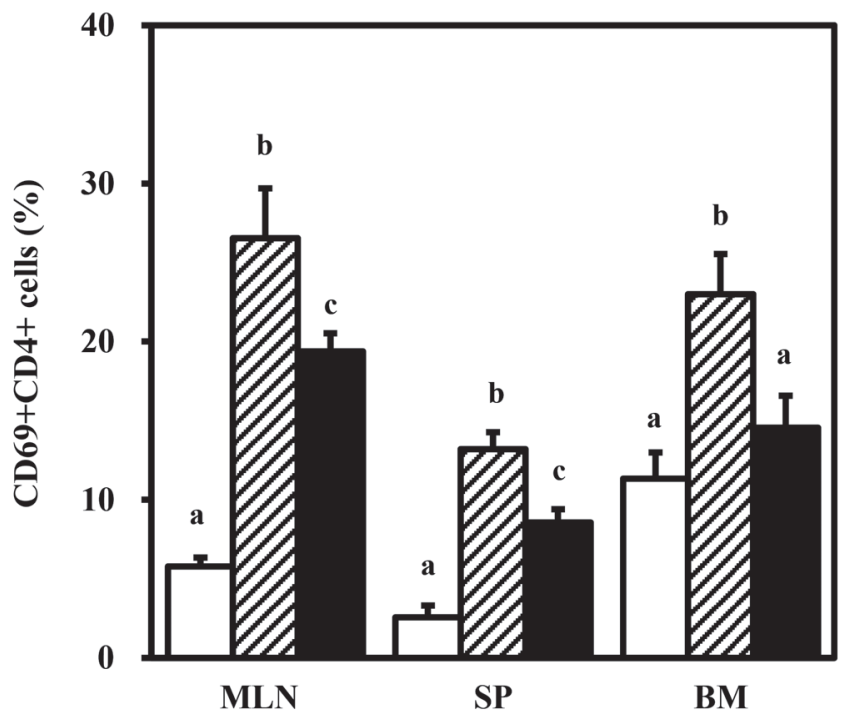

C

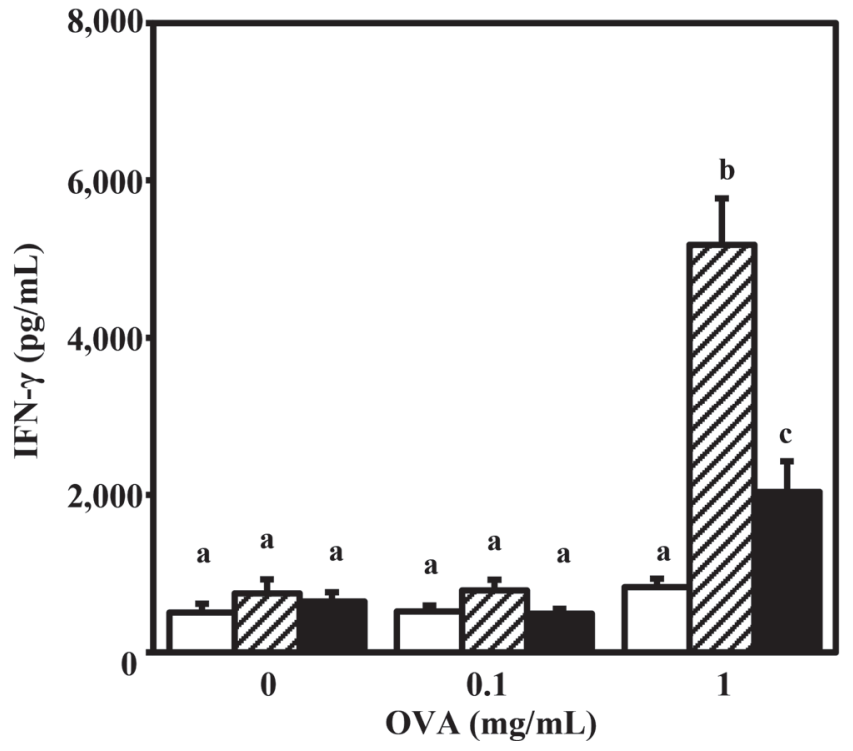

B

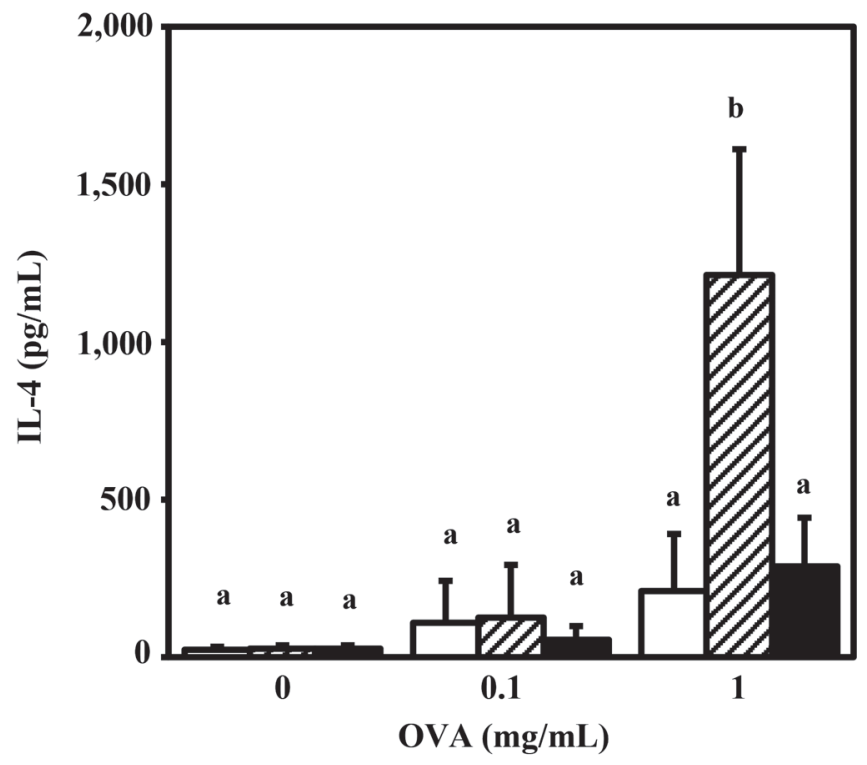

Figure 4. Effect of milk basic protein $(\mathrm{MBP})$ on the activation and cytokine production by $\mathrm{CD} 4^{+} \mathrm{T}$ cells in food-allergic enteropathy model mice. (A) The percentage of $\mathrm{CD} 69^{+} \mathrm{CD} 4^{+} \mathrm{T}$ cells in the total $\mathrm{CD} 4^{+} \mathrm{T}$ cell population and OVA-specific cytokine production; IL- 4 (B) and IFN- $\gamma$ (C) in BALB/cA mice fed the ovalbumin (OVA) diet (OVA/BALB group, white bar), and OVA23-3 mice fed the OVA diet (OVA/OVA23-3 group, diagonal striped bar) or the MBP/OVA diet (MBP/OVA/OVA23-3 group, black bar). Each value is mean $\pm \mathrm{SD}$; $\mathrm{n}=6$ for each group. Different letters represent significant differences, $P<0.05$, as determined by a post hoc Tukey-Kramer test. MLN $=$ mesenteric lymph node; $\mathrm{SP}=$ spleen; $\mathrm{BM}=$ bone marrow.

that excessive IL-4 production by $\mathrm{CD} 4^{+} \mathrm{T}$ cells in MLN prevented the induction of tolerance (NakajimaAdachi et al., 2017). Taking this study together with our findings suggests that MBP may induce tolerance by decreasing IL- 4 production by $\mathrm{CD} 4^{+} \mathrm{T}$ cells in MLN. The measurement of parameters associated with Tregs, such as transcription factor forkhead box P3 expression (Hori et al., 2003) and IL-10 production (Tsuji et al., 2001; Shiokawa et al., 2009) by CD4 $4^{+} \mathrm{T}$ cells, may determine whether MBP induces tolerance in food-allergic enteropathy model mice. Further studies are required to clarify this issue. In addition, the effect of MBP on enteropathy needs to be investigated in detail in the future; because the collection of tissues in our study was done on d 28 when the T-cell activation was suppressed, the inflammation was not severe even in the control (OVA/OVA23-3) group. Therefore, it was difficult to estimate the inhibitory effect of MBP 
Table 3. Bone mineral density $\left(\mathrm{mg} / \mathrm{cm}^{2}\right)$ of femur bones $(\text { mean } \pm \mathrm{SD}, \mathrm{n}=6 \text { for each group })^{1}$

\begin{tabular}{lccc}
\hline Item & OVA/BALB & OVA/OVA23-3 & MBP/OVA/OVA23-3 \\
\hline $\begin{array}{l}\text { Proximal } \\
\text { d 10 }\end{array}$ & $40.07 \pm 0.51$ & $38.95 \pm 1.96$ & $40.13 \pm 1.31$ \\
d 28 & $41.40 \pm 0.77$ & $40.59 \pm 0.60$ & $40.86 \pm 1.98$ \\
Diaphysis & & $36.76 \pm 0.67$ & $37.65 \pm 0.87$ \\
d 10 & $37.26 \pm 0.90$ & $37.05 \pm 0.53^{\mathrm{b}}$ & $38.25 \pm 0.68^{\mathrm{a}}$ \\
d 28 & $38.35 \pm 1.22^{\mathrm{a}}$ & $38.28 \pm 0.94$ & $39.27 \pm 0.87$ \\
Distal & $38.99 \pm 1.00$ & $39.94 \pm 1.11$ & $40.89 \pm 1.88$ \\
d 10 & $41.00 \pm 1.68$ & & \\
d 28 &
\end{tabular}

${ }^{\mathrm{a}, \mathrm{b}}$ Different superscripts indicate significant differences, $P<0.05$, as determined by a post hoc Tukey-Kramer test.

${ }^{1} \mathrm{MBP}=$ milk basic protein; OVA $=$ ovalbumin; OVA $/$ BALB group $=$ BALB $/$ cA mice were fed the OVA diet; OVA/OVA23-3 group = OVA23-3 mice were fed the OVA diet; MBP/OVA/OVA23-3 group = OVA23-3 mice were fed the MBP/OVA diet.

on the enteropathy, although the effect was observed. We could not show significant difference in BW change throughout the administration period between OVA/ OVA23-3 and MBP/OVA/OVA23-3 groups, suggesting that the inhibitory effect of MBP on local inflammation such as enteropathy may be weak; therefore, strict evaluation is required in the future.

A clinical study reported that celiac disease, a type of food-allergic enteropathy caused by autoimmune disease, induces bone loss (Alaedini and Greem, 2005). However, the precise pathogenic mechanisms underlying the onset of bone loss in this disease remain unclear. Stolina et al. (2005) reported that systemic activation of $\mathrm{T}$ cells and bone loss were observed in IL-2-deficient mice regarded as a model for colitis. Our study showed that feeding the OVA diet to OV23-3 mice induced $\mathrm{CD} 69^{+} \mathrm{CD} 4^{+} \mathrm{T}$ cells in the BM as well as in the MLN and spleen. In addition, OVA-fed OV23-3 mice exhibited bone loss together with enteropathy, suggesting that systemic inflammation related to T-cell-activation causes bone loss in these mice. Notably, MBP supplementation to OVA-fed OVA23-3 mice prevented bone loss accompanied with enteropathy. This bone protective effect of MBP may be due to the direct promotion of osteoblast-mediated bone formation and the direct inhibition of osteoclast-mediated bone resorption, as reported previously (Toba et al., 2000; Morita et al., 2012). Furthermore, indirect effects of MBP supplementation may be present, such as the production of OPG and the induction of Tregs. The induction of IL-10 by Tregs plays an inhibitory role in osteoclastogenesis (Mohamed et al., 2007), and thus MBP may have the possibility of promoting the induction of tolerance by suppressing excessive IL-4 production by $\mathrm{CD} 4^{+} \mathrm{T}$ cells, thereby inducing IL-10-producing-Tregs. A protective effect of OPG against bone loss is exerted by inhibiting osteoclastogenesis and bone resorption by neutralizing RANKL function (Bucay et al., 1998; Raisz, 2005). The increased serum OPG level in these food-allergic enteropathy mice may reflect the compensatory response of bone loss, in which osteoblasts produce OPG, as reported in other studies (Taranta et al., 2004; Fiore et al., 2006). Interestingly, we found that MBP supplementation increased the serum OPG level beyond the increase observed in food-allergic enteropathy mice (Table 2). Treating ovariectomized mice with LF was reported to increase the OPG level, accompanied by decreased bone loss (Hou et al., 2012). Furthermore, an intestinal epithelial cell line was also reported to produce OPG (Ariyasu et al., 2002), and consequently, the supplementation of MBP to the OVA diet may produce OPG beyond the compensatory response. This mechanism, in which MBP supplementation increased the level of serum OPG and prompted the recovery from bone loss in food-allergic enteropathy model mice, remains to be clarified by future studies.

In conclusion, MBP functioned to inhibit T-cell-activation, leading to suppression of cytokine production. The supplementation of MBP to the OVA diet exerted an anti-inflammatory effect in food-allergic enteropathy model mice by decreasing the serum IgE level by suppressing IL-4-producing CD4 ${ }^{+} \mathrm{T}$ cells of MLN, and prevented bone loss by systemically inhibiting inflammation. Because MBP is a complex comprising several proteins with different properties as described above, it suggests that the inhibitory effect of MBP on T-cellactivation may help control Th2- or Th17-cell-related diseases, as well as Th1-cell-related diseases, more effectively than individual milk proteins.

\section{ACKNOWLEDGMENTS}

Financial support for this work was provided by Megmilk Snow Brand Co., Ltd (Tokyo, Japan). We thank S. Habu (Tokai University School of Medicine, Japan) for providing the OVA23-3 mice and T. Nara (Megmilk 
Snow Brand Co., Ltd.) for assistance with writing the draft manuscript.

\section{REFERENCES}

Alaedini, A., and P. H. Greem. 2005. Narrative review: Celiac disease: Understanding a complex autoimmune disorder. Ann. Intern. Med. 142:289-298.

American Institute of Nutrition. 1977. Report of the American Institute of Nutrition ad hoc Committee on Standards for Nutritional Studies. J. Nutr. 107:1340-1348.

Aoe, S., T. Koyama, Y. Toba, A. Itabashi, and Y. Takada. 2005. A controlled trial of the effect of milk basic protein (MBP) supplementation on bone metabolism in healthy menopausal women. Osteoporos. Int. 16:2123-2128.

Aoe, S., Y. Toba, J. Yamamura, H. Kawakami, M. Yahiro, and M. Kumegawa. 2001. Controlled trial of the effects of milk basic protein (MBP) supplementation on bone metabolism in healthy adult women. Biosci. Biotechnol. Biochem. 65:913-918.

Aoyagi, Y., H. Park, S. Park, K. Yoshiuchi, H. Kikuchi, and H. Kawakami. 2010. Interactive effects of milk basic protein supplements and habitual physical activity on bone health in older women: A 1-year randomized controlled trial. Int. Dairy J. 20:724-730.

Ariyasu, T., C. Arai, C. Yoshizane, F. Kyono, T. Hanaya, S. Arai, M Ikeda, and M. Kurimoto. 2002. Trehalose augments osteoprotegerin production in the FHs74Int human intestinal epithelial cell line. In Vitro Cell. Dev. Biol. Anim. 38:30-34.

Bernstein, C. N. 2006. Inflammatory bowel diseases as secondary causes of osteoporosis. Curr. Osteoporos. Rep. 4:116-123.

Bernstein, C. N., and W. D. Leslie. 2003. The pathophysiology of bone disease in gastrointestinal disease. Eur. J. Gastroenterol. Hepatol. 15:857-864.

Bharadwaj, S., A. G. Naidu, G. V. Betageri, N. V. Prasadarao, and A. S. Naidu. 2009. Milk ribonuclease-enriched lactoferrin induces positive effects on bone turnover markers in postmenopausal women. Osteoporos. Int. 20:1603-1611.

Bucay, N., I. Sarosi, C. R. Dunstan, S. Morony, J. Tarpley, and C. Capparelli. 1998. Osteoprotegerin-deficient mice develop early onset osteoporosis and arterial calcification. Genes Dev. 12:1260-1268.

Chen, L., and D. B. Flies. 2013. Molecular mechanisms of T cell costimulation and co-inhibition. Nat. Rev. Immunol. 13:227-242.

Fiore, C. E., P. Pennisi, G. Ferro, B. Ximenes, L. Privitelli, R. A. Mangiafico, F. Santoro, N. Parisi, and T. Lombardo. 2006. Altered osteoprotegerin/RANKL ratio and low bone mineral density in celiac patients on long-term treatment with gluten-free diet. Horm. Metab. Res. 38:417-422.

Fischer, R., H. Debbabi, M. Dubarry, P. Boyaka, and D. Tomé. 2006. Regulation of physiological and pathological Th1 and Th2 responses by lactoferrin. Biochem. Cell Biol. 84:303-311.

Franchimont, N., C. Reenaers, C. Lambert, J. Belaiche, V. Bours, M. Malaise, P. Delvenne, and E. Louis. 2004. Increased expression of receptor activator of NF-kappaB ligand (RANKL), its receptor RANK and its decoy receptor osteoprotegerin in the colon of Crohn's disease patients. Clin. Exp. Immunol. 138:491-498.

Goodman, R. E., S. L. Taylor, J. Yamamura, T. Kobayashi, H. Kawakami, C. L. Kruger, and G. P. Thompson. 2007. Assessment of the potential allergenicity of a milk basic protein fraction. Food Chem. Toxicol. 45:1787-1794.

Gordon, C. M. 2006. Bone loss in children with Crohn disease: Evidence of "osteoimmune" alterations. J. Pediatr. 148:429-432.

Grabenhenrich, L. B., S. Dölle, A. Moneret-Vautrin, A. Köhli, L. Lange, T. Spindler, F. Ruëff, K. Nemat, I. Maris, E. Roumpedaki, K. Scherer, H. Ott, T. Reese, T. Mustakov, R. Lang, M. Fernandez-Rivas, M. L. Kowalski, M. B. Bilò, J. O. Hourihane, N. G. Papadopoulos, K. Beyer, A. Muraro, and M. Worm. 2016. Anaphylaxis in children and adolescents: The European Anaphylaxis Registry. J. Allergy Clin. Immunol. 137:1128-1137.

Hori, S., T. Nomura, and S. Sakaguchi. 2003. Control of regulatory $\mathrm{T}$ cell development by the transcription factor Foxp3. Science 299:1057-1061.
Hou, J. M., Y. Xue, and Q. M. Lin. 2012. Bovine lactoferrin improves bone mass and microstructure in ovariectomized rats via OPG/ RANKL/RANK pathway. Acta Pharmacol. Sin. 33:1277-1284.

Ishida, Y., T. Yasueda, H. Murakami, and K. Kato. 2017. Absorption of bovine angiogenin into peripheral blood of rats orally administered milk basic protein. Biosci. Biotechnol. Biochem. 81:604-607.

Kato, K., Y. Toba, H. Matsuyama, J. Yamamura, Y. Matsuoka, H. Kawakami, A. Itabashi, M. Kumegawa, S. Aoe, and Y. Takada. 2000. Milk basic protein enhances the bone strength in ovariectomized rats. J. Food Biochem. 24:467-476.

Kruger, C. L., K. M. Marano, Y. Morita, Y. Takada, H. Kawakami, T. Kobayashi, M. Sunaga, M. Furukawa, and K. Kawamura. 2007. Safety evaluation of a milk basic protein fraction. Food Chem. Toxicol. 45:1301-1307.

Kuwabara, T., F. Ishikawa, M. Kondo, and T. Kakiuchi. 2017. The role of IL-17 and related cytokines in inflammatory autoimmune diseases. Mediators Inflamm. 2017:3908061.

Legrand, D. 2012. Lactoferrin, a key molecule in immune and inflammatory processes. Biochem. Cell Biol. 90:252-268.

Legrand, D. 2016. Overview of lactoferrin as a natural immune modulator. J. Pediatr. 173:S10-S15.

Lindelöf, B., F. Granath, M. Tengvall-Linder, H. Lindelöf, and A. Ekbom. 2009. Allergy and autoimmune disease: A registry-based study. Clin. Exp. Allergy 39:110-115.

Lordan, R., and I. Zabetakis. 2017. Invited review: The anti-inflammatory properties of dairy lipids. J. Dairy Sci. 100:4197-4212.

Low, P. P., K. J. Rutherfurd, H. S. Gill, and M. L. Cross. 2003. Effect of dietary whey protein concentrate on primary and secondary antibody responses in immunized BALB/c mice. Int. Immunopharmacol. 3:393-401.

Luo, L., G. Zhu, H. Xu, S. Yao, G. Zhou, Y. Zhu, K. Tamada, L. Huang, A. D. Flies, M. Broadwater, W. Ruff, J. M. van Deursen, I. Melero, Z. Zhu, and L. Chen. 2015. B7-H3 promotes pathogenesis of autoimmune disease and inflammation by regulating the activity of different T cell subsets. PLoS One 10:e0130126.

Matsuoka, Y., A. Serizawa, T. Yoshioka, J. Yamamura, Y. Morita, and H. Kawakami. 2002. Cystatin C in milk basic protein (MBP) and its inhibitory effect on bone resorption in vitro. Biosci. Biotechnol. Biochem. 66:2531-2536.

Mohamed, S. G., E. Sugiyama, K. Shinoda, H. Taki, H. Hounoki, H. O. Abdel-Aziz, M. Maruyama, M. Kobayashi, H. Ogawa, and T. Miyahara. 2007. Interleukin-10 inhibits RANKL-mediated expression of NFATc1 in part via suppression of c-Fos and c-Jun in RAW264.7 cells and mouse bone marrow cells. Bone 41:592-602.

Mohanty, D. P., S. Mohapatra, S. Misra, and P. S. Sahu. 2016. Milk derived bioactive peptides and their impact on human health-A review. Saudi J. Biol. Sci. 23:577-583.

Morita, Y., H. Matsuyama, A. Serizawa, T. Takeya, and H. Kawakami. 2008. Identification of angiogenin as the osteoclastic bone resorption-inhibitory factor in bovine milk. Bone 42:380-387.

Morita, Y., A. Ono, A. Serizawa, K. Yogo, N. Ishida-Kitagawa, T. Takeya, and T. Ogawa. 2011. Purification and identification of lactoperoxidase in milk basic proteins as an inhibitor of osteoclastogenesis. J. Dairy Sci. 94:2270-2279.

Morita, Y., A. Ono-Ohmachi, S. Higurashi, H. Matsuyama, A. Serizawa, and T. Takeya. 2012. The bone-strengthening activity of milk basic protein is not dependent on lactoferrin. Int. Dairy J. $27: 40-46$.

Moschen, A. R., A. Kaser, B. Enrich, O. Ludwiczek, M. Gabriel, P. Obrist, A. M. Wolf, and H. Tilg. 2005. The RANKL/OPG system is activated in inflammatory bowel disease and relates to the state of bone loss. Gut 54:479-487.

Nakajima-Adachi, H., A. Ebihara, A. Kikuchi, T. Ishida, K. Sasaki, K. Hirano, H. Watanabe, K. Asai, Y. Takahashi, Y. Kanamori, N. Shimojo, H. Matsuda, Y. Kohno, S. Hachimura, and S. Kaminogawa. 2006. Food antigen causes TH2-dependent enteropathy followed by tissue repair in T-cell receptor transgenic mice. J. Allergy Clin. Immunol. 117:1125-1132.

Nakajima-Adachi, H., A. Kikuchi, Y. Fujimura, K. Shibahara, T. Makino, M. Goseki-Sone, M. Kihara-Fujioka, T. Nochi, Y. Kurashima, O. Igarashi, M. Yamamoto, J. Kunisawa, M. Toda, S. Kaminoga- 
wa, R. Sato, H. Kiyono, and S. Hachimura. 2014. Peyer's patches and mesenteric lymph nodes cooperatively promote enteropathy in a mouse model of food allergy. PLoS One 9:e107492.

Nakajima-Adachi, H., K. Shibahara, Y. Fujimura, J. Takeyama, E. Hirade, A. Kikuchi, H. Murakami, A. Hosono, T. Nochi, Y. Wakatsuki, N. Shimojo, S. Kaminogawa, R. Sato, H. Kiyono, and S. Hachimura. 2017. Critical role of intestinal interleukin-4 modulating regulatory $\mathrm{T}$ cells for desensitization, tolerance, and inflammation of food allergy. PLoS One 12:e0172795.

Otani, H. 2006. A conclusion relating to actual and potential biodefensive functions of bovine milk proteins via immune systems. Milk Science (Japanese) 55:1-14.

Raisz, L. G. 2005. Pathogenesis of osteoporosis: Concepts, conflicts, and prospects. J. Clin. Invest. 115:3318-3325.

Shiokawa, A., K. Tanabe, N. M. Tsuji, R. Sato, and S. Hachimura. 2009. IL-10 and IL-27 producing dendritic cells capable of enhancing IL-10 production of T cells are induced in oral tolerance. Immunol. Lett. 125:7-14.

Silvennoinen, J. A., T. J. Karttunen, S. E. Niemelä, J. J. Manelius, and J. K. Lehtola. 1995. A controlled study of bone mineral density in patients with inflammatory bowel disease. Gut 37:71-76.

Simons, F. E., M. Ebisawa, M. Sanchez-Borges, B. Y. Thong, M. Worm, L. K. Tanno, R. F. Lockey, Y. M. El-Gamal, S. G. Brown, H. S. Park, and A. Sheikh. 2015. 2015 update of the evidence base: World Allergy Organization anaphylaxis guidelines. World Allergy Organ. J. 8:32.

Stolina, M., S. Adman, M. Ominsky, D. Dwyer, F. Asuncion, Z. Geng, S. Middleton, H. Brown, J. Pretorius, G. Schett, B. Bolon, U. Feige, D. Zack, and P. J. Kostenuik. 2005. RANKL is a marker and mediator of local and systemic bone loss in two rat models of inflammatory arthritis. J. Bone Miner. Res. 20:1756-1765.

Tanigawa, K., M. Fujihara, R. Sakamoto, S. Yanahira, and K. Ohtsuki. 2001. Characterization of bovine angiogenin-1 and lactogenin-like protein as glycyrrhizin-binding proteins and their in vitro phosphorylation by C-kinase. Biol. Pharm. Bull. 24:443-447.

Taranta, A., D. Fortunati, M. Longo, N. Rucci, E. Iacomino, F. Aliberti, E. Facciuto, S. Migliaccio, M. T. Bardella, A. Dubini, M. O.
Borghi, S. Saraifoger, A. Teti, and M. L. Bianchi. 2004. Imbalance of osteoclastogenesis-regulating factors in patients with celiac disease. J. Bone Miner. Res. 19:1112-1121.

Toba, Y., Y. Takada, J. Yamamura, M. Tanaka, Y. Matsuoka, and H. Kawakami. 2000. Milk basic protein: a novel protective function of milk against osteoporosis. Bone 27:403-408.

Togawa, J., H. Nagase, K. Tanaka, M. Inamori, T. Umezawa, A. Nakajima, M. Naito, S. Sato, T. Saito, and H. Sekihara. 2002. Lactoferrin reduces colitis in rats via modulation of the immune system and correction of cytokine imbalance. Am. J. Physiol. Gastrointest. Liver Physiol. 283:G187-G195.

Tsuji, N. M., K. Mizumachi, and J. Kurisaki. 2001. Interleukin-10-secreting Peyer's patch cells are responsible for active suppression in low-dose oral tolerance. Immunology 103:458-464.

Wong, C. W., H. F. Seow, A. J. Husband, G. O. Regester, and D. L. Watson. 1997. Effects of purified bovine whey factors on cellular immune functions in ruminants. Vet. Immunol. Immunopathol. $56: 85-96$.

Wong, C. W., and D. L. Watson. 1995. Immunomodulatory effects of dietary whey proteins in mice. J. Dairy Res. 62:359-368.

Yamamura, J., Y. Morita, Y. Takada, and H. Kawakami. 2006. The fragments of bovine high molecular weight kininogen promote osteoblast proliferation in vitro. J. Biochem. 140:825-830.

Yamamura, J., Y. Takada, M. Goto, M. Kumegawa, and S. Aoe. 1999. High mobility group-like protein in bovine milk stimulates the proliferation of osteoblastic MC3T3-E1 cells. Biochem. Biophys. Res. Commun. 261:113-117.

Yamamura, J., Y. Takada, M. Goto, M. Kumegawa, and S. Aoe. 2000. Bovine milk kininogen fragment 1.2 promotes the proliferation of osteoblastic MC3T3-E1 cells. Biochem. Biophys. Res. Commun. 269:628-632

Zimecki, M., J. Mazurier, G. Spik, and J. A. Kapp. 1996. Lactoferrin inhibits proliferative response and cytokine production of TH1 but not TH2 cell lines. Arch. Immunol. Ther. Exp. (Warsz.) 44:51-56. 